\title{
A possible human homologue for the mouse mutant disorganisation
}

\author{
ROBIN M WINTER* AND DIAN DONNAI $\dagger$ \\ From ${ }^{*}$ the Kennedy Galton Centre, Clinical Research Centre, Northwick Park Hospital, Harrow, Middlesex \\ HA1 3UJ; and †Department of Medical Genetics, St Mary's Hospital, Hathersage Road, Manchester \\ M13 OJH.
}

SUMmaRY The mouse mutant disorganisation (Ds) is a semidominant gene with variable penetrance in heterozygotes and lethality in homozygotes; $67 \%$ of heterozygotes have multiple defects and the rest have single defects. Fifty-three percent have cranioschisis and exencephaly, $40 \%$ have hamartomas represented by papillae of variable size and shape protruding from the body, sometimes containing cartilage, and 33\% have limb abnormalities.

A child is presented with defects similar to those seen in mice heterozygous for Ds. He had shortening of the upper and lower segments of the right leg with a popliteal web and nine toes on the same side. A finger-like structure arose from the abdomen and one kidney was absent.

The homology between this infant and Ds mice is discussed and published reports of human cases with similar abnormalities are reviewed.

The mouse mutant disorganisation (Ds) was first fully described by Hummel, ${ }^{2}{ }^{2}$ who stated that it received its name "from the fact that it disrupts the orderly processes of organogenesis and induces a great variety of developmental anomalies in structures derived from germ layers". The mutant is autosomal dominant with lethality in homozygotes and incomplete penetrance in heterozygotes. In affected heterozygotes, approximately two-thirds of animals have multiple defects and one-third single defects. The range of abnormalities caused by the mutation is shown in table 1 . These can be roughly grouped into craniofacial abnormalities (cranioschisis/exencephaly, facial clefting, eye defects, pharyngeal defects), limb abnormalities (duplication and reduction, polydactyly, malformation of limb girdles), urogenital abnormalities (exstrophy/duplication of bladder, fused, cystic, or absent kidneys, malpositioned, atretic genital tracts), gastroschisis, and hamartomas. The hamartomas are an extremely interesting manifestation of the gene. They project from body surfaces and can resemble limbs, digits, urogenital papillae, mammae, or undifferentiated evaginations of skin. The hamartomas can also manifest as nodules in body walls and cavities and are made up of mixtures of tissues and

Received for publication 7 February 1989. Accepted for publication 9 February 1989.
TABLE 1 Disorganisation (Ds): summary of abnormalities found in mice (from Hummel ${ }^{\prime}$ ).

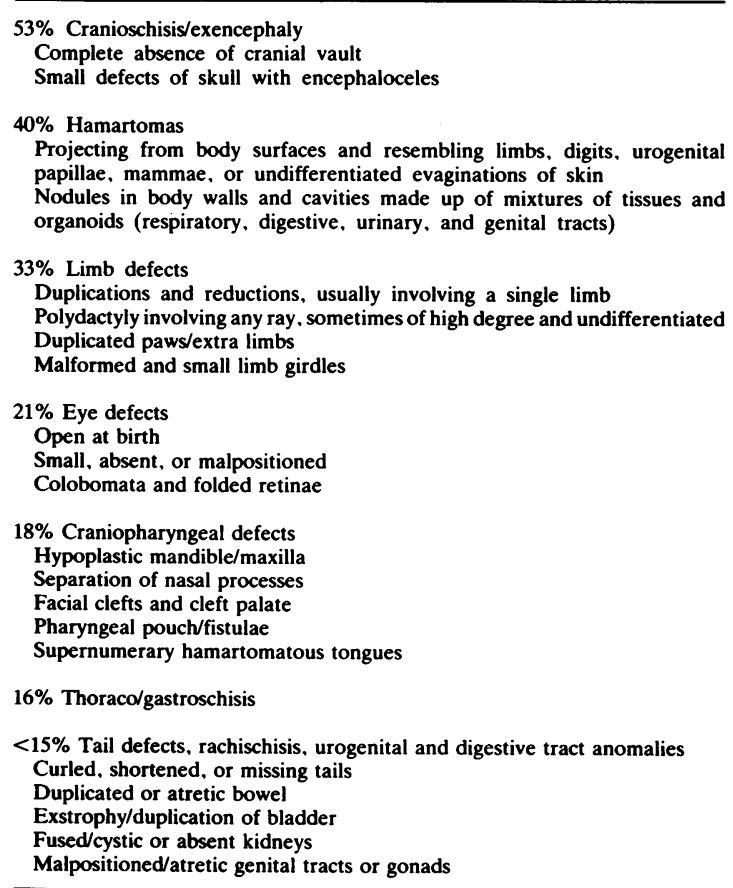


organoids (for example, respiratory, digestive, urinary, or genital tract).

With such a variable gene, causing often lethal malformations, it is difficult to identify human subjects who might have a homologous mutation. We present a child with features very similar to the manifestations of the mouse gene disorganisation and review similar published cases.

\section{Case report}

This is the second child born to a healthy, nonconsanguineous 25 year old mother and a 30 year

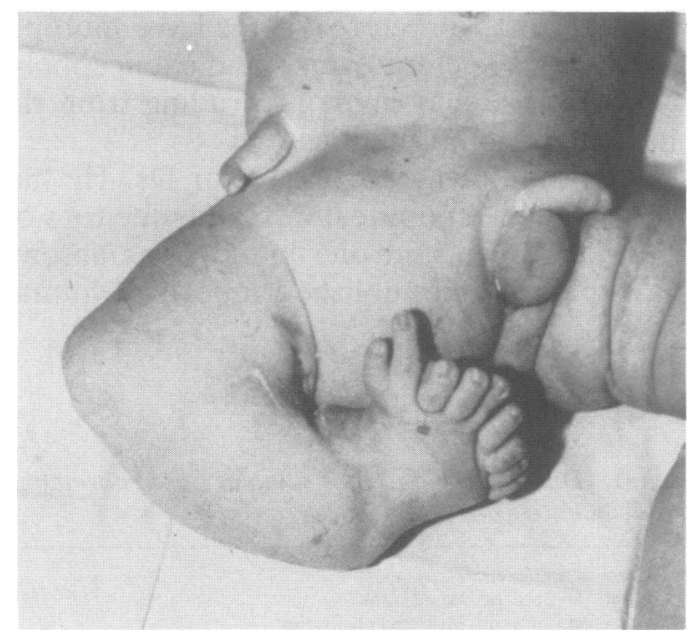

FIG 1 Abdomen and lower limbs. Note inverted right foot with nine toes, digit-like structure arising from lower abdomen, and fat pad in right groin. old father. An older brother is healthy. The pregnancy and birth were normal and the child's neonatal and early development have been within normal limits. On examination at four months there was a severe abnormality of the right leg, with shortening of the upper and lower segments and a web across the popliteal fossa, with flexion of the knee. The foot was inverted and had nine toes, none being identifiable as a hallux (fig 1). There was a large pad of tissue in the right groin and another over the right buttock with overlying flat vascular naevi. Just above the right anterior superior iliac spine a digit was attached to the abdominal wall. This digit contained bone and muscle and had a nail on the terminal 'phalanx' (fig 2). The left leg and both arms were entirely normal. Radiological investigations showed absence of the right kidney.

\section{Discussion}

The abnormalities caused by the mouse mutant gene disorganisation are many and various. They are summarised in table 1. Many of the abnormalities would be classified as multifactorial in origin, or sporadic, if seen in isolation in a human fetus or neonate. It is only if they appeared in unusual combinations in the same person that homology with the mouse mutant gene might be questioned. The case presented here has a very unusual combination of a high degree of polydactyly on one leg, a digit arising from the lower abdomen, and an absent kidney. It is difficult to explain these defects using classical embryological theory, and there is convincing similarity to the phenotypic effects of the mouse disorganisation gene.

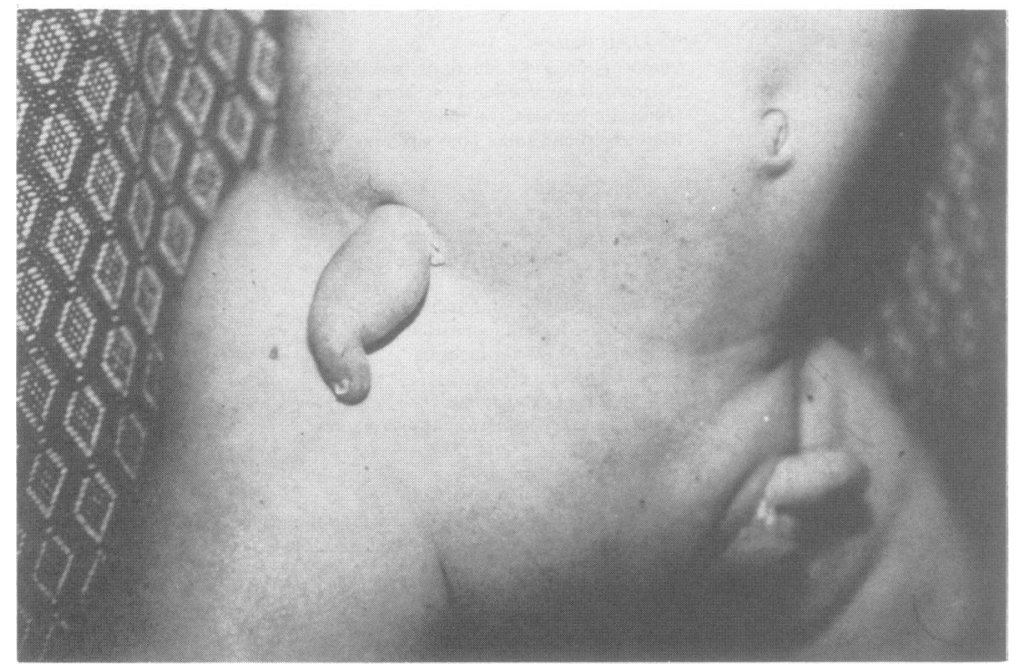

FIG 2 Close up of digit-like structure arising from abdomen; note nail. 
TABLE 2 Summary of cases with duplicated lower limbs.

\begin{tabular}{|c|c|c|}
\hline Report & Limb defects & Other abnormalities \\
\hline Wells $^{3}$ (Case: Blanche Dumas) & $\begin{array}{l}\text { Extra leg and traces } \\
\text { of a fourth }\end{array}$ & $\begin{array}{l}\text { Dual independent external } \\
\text { genitalia. Extra breast by } \\
\text { the side of the fourth leg }\end{array}$ \\
\hline Zammit $^{4}$ & $\begin{array}{l}\text { Extra leg arising from } \\
\text { pelvis posteriorly }\end{array}$ & $\begin{array}{l}\text { Appendage containing bone below } \\
\text { knee of extra limb. Clitoris } \\
\text { and labium at base of extra } \\
\text { limb. Mucous membrane covered } \\
\text { tumour the size of an orange } \\
\text { covered by 'labium' }\end{array}$ \\
\hline Deboo $^{5}$ & $\begin{array}{l}\text { Extra hypoplastic leg } \\
\text { between normal pair }\end{array}$ & $\begin{array}{l}\text { Two urethras. Abnormal ischial } \\
\text { and pubic bones }\end{array}$ \\
\hline Smillie and Murdoch ${ }^{6}$ & $\begin{array}{l}\text { Extra leg arising from } \\
\text { right side of buttock. } \\
\text { Accessory toe arising } \\
\text { from 1st metatarsal of } \\
\text { extra foot }\end{array}$ & $\begin{array}{l}\text { Extra scrotum and penis with } \\
\text { bifid glans. Glans and blind } \\
\text { ending urethra arising from } \\
\text { anteromedial aspect of extra } \\
\text { leg }\end{array}$ \\
\hline Norman $^{7}$ & $\begin{array}{l}\text { Extra leg with three } \\
\text { toes arising from left } \\
\text { buttock }\end{array}$ & $\begin{array}{l}\text { Cyst in 'buttock' of extra leg. } \\
\text { Two digit-like fibroepithelial } \\
\text { polyps arising from surface of } \\
\text { the cyst }\end{array}$ \\
\hline Srivastava and Garg ${ }^{8}$ & $\begin{array}{l}\text { Partial duplication of } \\
\text { right foot. Eight toes } \\
\text { in all. Double femora, } \\
\text { single tibia, duplication } \\
\text { of fibula }\end{array}$ & \\
\hline $\begin{array}{l}\text { Cornah and } \\
\text { Dangerfield }^{9}\end{array}$ & $\begin{array}{l}\text { Shortening of right leg. } \\
\text { Duplicated femur, absent tibia }\end{array}$ & \\
\hline Taniguchi et $a l^{10}$ & $\begin{array}{l}\text { Extra hypoplastic leg } \\
\text { arising from left } \\
\text { buttock. Five undifferentiated } \\
\text { toes }\end{array}$ & $\begin{array}{l}\text { Anal atresia. Rectovesicular } \\
\text { fistula. Absent left kidney; } \\
\text { hyperplasia of right kidney } \\
\text { with vesicoureteric reflex }\end{array}$ \\
\hline Billett and Bear ${ }^{11}$ & $\begin{array}{l}\text { Duplicated right foot } \\
\text { with seven toes }\end{array}$ & $\begin{array}{l}\text { Absent right kidney. Postero- } \\
\text { medial mass arising from right } \\
\text { buttock, mainly adipose } \\
\text { tissue }\end{array}$ \\
\hline Hanley and Stanitski ${ }^{12}$ & $\begin{array}{l}\text { Duplicated left foot } \\
\text { with six undifferentiated } \\
\text { toes. Duplicated tibia }\end{array}$ & \\
\hline Stevenson et $a l^{13}$ & $\begin{array}{l}\text { Reduction of right leg } \\
\text { with absent foot. Foot } \\
\text { with four toes arising } \\
\text { from perineum }\end{array}$ & $\begin{array}{l}\text { Absent right kidney. "Disrupted } \\
\text { genital morphology" } * \text {. Hemi- } \\
\text { vertebrae D8, D11, disorganised } \\
\text { sacrococcygeal vertebrae. } \\
\text { Spinal dermoid (? with ectopic } \\
\text { Wilms' tumour). Lipoma of cord }\end{array}$ \\
\hline $\begin{array}{l}\text { Schooley and } \\
\text { Leichtman }^{14}\end{array}$ & $\begin{array}{l}\text { Atrophy of left leg. } \\
\text { Third 'hypoplastic leg' } \\
\text { arising from base of } \\
\text { fluid filled sac over } \\
\text { lower lumbar spine and } \\
\text { sacrum }\end{array}$ & $\begin{array}{l}\text { Duplicated external female } \\
\text { genitalia with three labia } \\
\text { majora and two vaginal openings. } \\
\text { Left rectovaginal fistula. } \\
\text { Very abnormal vertebrae } \\
\text { below } L 1 . \text { Maternal } \\
\text { trauma at three and } 10 \text { weeks' } \\
\text { gestation }\end{array}$ \\
\hline Weisselberg et $a l^{15}$ & $\begin{array}{l}\text { Duplicated left foot } \\
\text { with three digits. } \\
\text { Duplicated fibula }\end{array}$ & $\begin{array}{l}\text { Absent left kidney. Hydro- } \\
\text { uretonephrosis of right } \\
\text { kidney. Prolapse of rectum. } \\
\text { Hyperextensible joints. Loose } \\
\text { skin }\end{array}$ \\
\hline Present case & $\begin{array}{l}\text { Shortened right leg } \\
\text { with popliteal web. } \\
\text { Right foot with nine } \\
\text { undifferentiated toes }\end{array}$ & $\begin{array}{l}\text { Finger-like structure arising } \\
\text { from abdomen. Large pad of } \\
\text { tissue over right inguinal } \\
\text { region and over buttock. Absent } \\
\text { right kidney }\end{array}$ \\
\hline
\end{tabular}

*"*A $1 \mathrm{~cm}$ cutaneous protuberance without corporeal tissue or meatus at the usual position for the penis, a $1 \mathrm{~cm}$ slit-like urinary orifice located $1 \mathrm{~cm}$ posterior to this structure, palpable corporeal tissue embedded in the tissue to the left of this orifice, a left labioscrotal mound without a palpable gonad. Posterior to the labioscrotal mounds and the implanted foot was a slit-like anus." 
Review of published reports shows several case reports of persons with an extra lower or duplicated limb (table 2). In many of these cases there have been degrees of polydactyly associated with the extra limb, with additional features such as skin tags, lipomas or hamartomas, and genitourinary abnormalities.

For example, in the female reported by Wells ${ }^{3}$ there were dual independent external genitalia, two extra legs, and a breast like structure at the base of the fourth leg. In the case reported by $\mathrm{Zammit}^{4}$ there was an extra leg, which also had a small, fleshy appendage below the knee. There was a mucous membrane covered tumour the size of an orange at the base of the extra limb, which was interpreted as a clitoris and labium. More recently, the case reported by Schooley and Leichtman ${ }^{14}$ had a cyst over the lower spine, an extra hypoplastic leg arising from the base of this cyst, and duplicated external female genitalia. There were also multiple vertebral defects.

Several cases have had unilateral absent kidneys, for example, those of Taniguchi et al, ${ }^{10}$ Billett and Bear, ${ }^{11}$ Stevenson et al, ${ }^{13}$ Weisselberg et al, ${ }^{15}$ and the case presented here.

Families where there is clustering of different congenital abnormalities in several generations might point to the existence of a disorganisation-like gene. For example, Hoon and Hall ${ }^{16}$ have recently described a family in which a mother had both preaxial polydactyly and limb deficiency while the son had only limb deficiency. The maternal great grandmother was reported to have had a short left leg and a maternal first cousin on the mother's father's side had shortening of both fingers.

In view of the wide variety of abnormalities caused by the mouse disorganisation gene, it is obviously easy to overdiagnose possibly homologous human patients, who may have just one or two suggestive abnormalities. Features that should raise suspicion of a possible disorganisation-like gene are extra limbs, appendages, or hamartomatous structures, in association with polydactyly or partial duplication/reduction of limbs and apparently embryologically distinct malformations, such as urogenital, body wall, and craniofacial abnormalities. Asymmetry of malformations is a further pointer.

We would like to thank Dr J G Hall for pointing out the family segregating for a possible disorganisationlike gene ${ }^{16}$ and for helpful discussions.

\section{References}

1 Hummel KP. The inheritance and expression of Disorganization, an unusual mutation in the mouse. $J$ Exp Zool 1958;137: $389-423$.

2 Hummel PK. Developmental anomalies in mice resulting from action of the gene Disorganization, a semi-dominant lethal. Pediatrics 1959;23:212-21.

3 Wells BH. A unique monstrosity. Am J Obstet 1888;21:1265-71.

4 Zammit J. Posterior dichotomy: a three-legged boy. $\mathrm{Br} \mathrm{Med} \mathrm{J}$ $1898 ; \mathbf{i}: 1528$.

5 Deboo SN. A three legged person. Med Bull (Bombay) 1943;11:339.

6 Smillie IS, Murdoch JH. A man with three legs. J Bone Joint Surg (Br) 1952;34:630-5.

7 Norman WH. A child with three lower extremities. J Bone Joint Surg (Am) 1964;46:1755-8.

8 Srivastava KK, Garg LD. Reduplication of bones of lower extremity. J Bone Joint Surg (Am) 1971;53:1445-7.

9 Cornah MS, Dangerfield PH. Reduplication of the femur. J Bone Joint Surg (Br) 1974;56:744-5.

10 Taniguchi K, Aoki H, Kurimoto $\mathrm{H}$, Okamura T. Baby with a third leg. J Pediatr Surg 1975;10:143-4.

11 Billett DM, Bear JN. Partial duplication of the lower limb. $J$ Bone Joint Surg (Am) 1978;60:1143-5.

12 Hanley EN, Stanitski CL. Incomplete congenital duplication of a lower extremity. J Bone Joint Surg (Am) 1980;62:479-81.

13 Stevenson RE, Saul RA, Parham KJ, Bley R. Limb amputation with autotransplantation in one of twins. Proc Greenwood Genet Center 1983;2:23-6.

14 Schooley K, Leichtman L. Physical abuse of a pregnant woman: a possible teratogen. Dysmorphol Clin Genet 1987;1:17-20.

15 Weisselberg B, Ben-Ami T, Goodman RM. Partial duplication of the lower limb with agenesis of ipsilateral kidney-a new syndrome: report of a case and review of the literature. Clin Genet 1988;33:234-9.

16 Hoon A, Hall JG. Familial limb deficiency. Clin Genet 1988;34:141-2.

Correspondence to $\operatorname{Dr} \mathrm{R}$ M Winter, Kennedy Galton Centre, Clinical Research Centre, Northwick Park Hospital, Watford Road, Harrow, Middlesex HA1 3UJ. 